подвижного состава и сложных

технических систем железнодорожного транспорта (основные положения).- М.: OAO «РЖД», 2007. - 62c.

14. Менухова Т.А. Унификация понятий «коэффициент технической готовности», «коэффициент выпуска» и «коэффициент использования автомобилей» с учетом применения новых временных показателей / Т.А. Менухова // Транспортное дело России . - М., 2013. №1. - c.89-94.

15. Павлюченко С.H.

Государственно-частное партнерство:

боеготовность бизнеса / С.Н. Павлюченко // Вагонный парк. - Х., 2011. - №6. - с. 23-27.

\title{
УДКз36.64:629.5
}

\section{РОЗВИТОК СУДНОБУДІВНОЇ ІНДУСТРІЇ В КОНТЕКСТІ РЕФОРМУВАННЯ ТРАНСПОРТНОЇ СИСТЕМИ УКРАЇНИ}

\author{
Гришина Л.О., к.е.н., доцент, \\ Карась П.М. ., к.е.н., професор, \\ Приходько Н.В. к.е.н., доцент (НУК ім. адм.Макарова)
}

В статті визначено місце $і$ значення суднобудівної індустрії у забезпеченні функціонування транспортної системи країни. Досліджено стан суднобудівних підприємств та виявлено негативні аспекти як політичного, так і економічного впливу на створення ефективних умов діяльності галузі. Досліджено динаміку коливань обсягів виробництва, фінансових результатів та умов створення законодавчого та нормативного впровадження економічних важелів у діяльність галузі Сформульовано рекомендачії щуодо застосування інструментарію оновлення суднобудівної індустрії в аспекті забезпечення реформування і розвитку транспортної системи.

Ключові слова: транспортна система, водний транспорт, суднобудівна індустрія, підприємства суднобудування

\section{РАЗВИТИЕ СУДОСТРОИТЕЛЬНОЙ ИНДУСТРИИ В КОНТЕКСТЕ РЕФОРМИРОВАНИЯ ТРАНСПОРТНОЙ СИСТЕМЫ УКРАИНЫ}

\author{
Гришина Л.А., к.э.н., доцент, \\ Карась П.Н. ., К.э.н., професор, \\ Приходько Н.В. к.э.н., доцент (НУК им. адм.Макарова)
}

В статье определено место и значение судостроительной индустрии в обеспечении функиионирования транспортной системь странь. Исследовано состояние судострочтельных предприятий и выявлены негативные аспекты как политического, так и экономического влияния на создание эффективных условий деятельности отрасли. Исследована динамика колебаний объемов производства, финансовых результатов и условий создания законодательного и нормативного внедрения экономических рычагов в деятельность отрасли Сформулированы рекомендации по применению инструментария обновления судостроительной

(С Гришина Л.О.,

Карась П.М., Приходько Н.В.

Вісник економіки транспорту і промисловості № 58, 2017 
индустрии в аспекте обеспечении реформирования $и$ развития

транспортной системьл.

Ключевые слова: транспортная система, водный транспорт, судострочтельная промышленность, предприятия судостроения

\title{
SHIPBUILDING INDUSTRY DEVELOPMENT IN THE CONSTRUCTION TRANSPORT SYSTEM OF UKRAINE
}

\author{
Gryshyna L., PhD Economics, associate professor, \\ Karas P., PhD Economics, professor, \\ Prikhodko N., PhD Economics, associate professor \\ (Admiral Makarov National Universityof Shipbuilding)
}

The article defines the place and importance of the shipbuilding industry in the operation of the transport system of the country. One of the most attractive components of the transport system supports aquatic (marine) transportation. This requires efficient functioning of the shipbuilding industry, which has considerable scientific-technical and production potential.

Investigated the state of shipbuilding enterprises during the formation of Ukraine as an independent sea power. Identified negative aspects of both political and economic influence on the creation of effective conditions of the industry. In today's challenging post-crisis economic conditions (inflation, rising prices for steel, the lack of financial resources, energy supply and components) the activities of the ukrainian shipbuilders has not yet become the key to the formation of a competitive domestic shipbuilding.

Investigated the dynamics of fluctuations in production volumes, financial results and conditions for the establishment of legislative and regulatory implementation of economic instruments in the industry.

Recommendations on the use of tools update shipbuilding industry in the development of the transport system. Support the domestic shipbuilding industry by the state, creating conditions for attracting investment, providing tax and other benefits will contribute to the effective functioning of the marine complex of Ukraine. This is an important way to deepen Ukraine's integration into European and world transport systems.

Keywords: transport system, water transport, shipbuilding industry, shipbuilding enterprises

Постановка проблеми у загальному вигляді. Сучасні посткризові умови господарювання вимагають використання стратегічних ресурсів базових видів економічної діяльності, серед яких вагоме місце займає транспортна сфера. Ефективне використання транспорту сприяе інтенсивному розвитку національної економіки, що обумовлює необхідність забезпечення чіткого і взаємопов'язаного функціонування транспортної системи країни. Одним із найбільш привабливих складових транспортної системи виступають водні (морські) перевезення, як найбільш ефективний спосіб доставки вантажів внаслідок низької іiї собівартості та можливостей вирішувати проблеми перевезення великогабаритних вантажів. Проте, сучасний стан рухомого складу морського і річкового транспорту свідчить про їх значне моральне i фізичне спрацювання. Вітчизняні торгові судна мають середній термін експлуатації більше 30 років, їх незадовільний технічний стан заважає виконувати 
зовнішньоекономічну

комерційну

діяльність, оскільки більшість західних країн забороняє вхід на внутрішній рейд таким транспортним засобам. Наявна портова інфраструктура, яка була сформована ще у минулому сторіччі, не змозі забезпечити якісне обслуговування замовників транзитних перевезень, вчасну переробку вантажів. До того ж, більше $30 \%$ причального фронту вітчизняних морських портів має незадовільний технічний стан та експлуатується 3 обмеженими технологічними навантаженнями. Тому однією 3 причин скорочення обсягів перевезень водним транспортом слід вважати фізичну i моральну застарілість вітчизняного флоту i портової інфраструктури, відсутність необхідних інвестицій для проведення ремонту та модернізації суден, а також у будівництво нового рухомого складу. За таких умов актуальним завданням $\epsilon$ оновлення техніко-технологічної бази водного транспорту, що в свою чергу, вимагає дієвого функціонування суднобудівної індустрії, яка поки що не втратила свій науково-технічний i виробничий потенціал. Продукція суднобудівних підприємств дозволить значно збільшити обсяги переробки вантажів морськими та річковими портами, товарної продукції сільського господарства, харчової та хімічної промисловості, забезпечити тисячі робочих місць в транспортній сфері. Відтак виникають нагальні потреби у відновленні і розвитку суднобудівної індустрії, що відповідають вимогам реформування транспортного комплексу України в умовах іiі інтеграції до світової транспортної системи.

Аналіз досліджень і публікацій. Вивчаючи літературні джерела 3 цього питання, було виявлено, що дослідженням різних аспектів розвитку транспортної системи присвячені праці провідних вітчизняних та зарубіжних науковців: Б. Буркинського, В. Вінникова, С. Свсєєва, О. Єдіна, О. Котлубая, А. Кульмана, А.
Маловичка, I. Могильовкіна, В. Новіцького, В. Ойкена, Ю. Пащенка, С. Пирожкова, К. Плужнікова, М. Примачева, А. Рибчука, Д-П. Родриго, Б.Слака, П. Сьоміна, О.Чернеги, Ю. Щєрбаніна та ін. [2;7;17;20]. Питання відновлення i розвитку суднобудувної індустрії, створення нового морегосподарського комплексу та формування його логістичної інфраструктури, стали об'єктом дослідження зарубіжних та вітчизняних вчених, а саме: В. Александрова, Н. Александровскої, А. Брехова, Н. Сгорова, Г. Сфімової, В. Жихаревої, І. Іртищевої, А. Капустіна, В. Коваля, О. Котлубая, С. Логочева, В. Лисицького, В. Макагона, О. Наумова, Д. Пашко, Т. Ротанова, С. Рижкова, С. Швець та інших [4; 7; 8; 13; $14 ; 15 ; 16]$. Проблеми відновлення та розвитку суднобудування розглядаються в контексті визнання України як морської держави, яка має найбільшу протяжність приморської смуги, розвинений морегосподарський комплекс у забезпеченні транспортування вантажів через вітчизняні та транзитні порти. Саме на сучасному i майбутньому етапах розвитку суспільства нестримно зростає роль Світового океану, його використання стає вирішальною умовою прискореного розвитку світової економіки i найважливішим чинником геополітики.

Виділення невирішених раніше частин загальної проблеми. Реалії функціонування сучасної транспортної системи України свідчать про іiі невідповідність зростаючим потребам суспільства у відповідних видах діяльності, вимогам європейських стандартів якості надання транспортних послуг. Серед основних факторів, що стримують використання потенціалу транспортної системи України, $є$ відсутність чіткого механізму реалізації стратегій розвитку транспортної сфери, відсутність власного морського флоту, низький рівень контейнеризації портового господарства, низький рівень

Вісник економіки транспорту і промисловості № 58, 2017 
конкурентоспроможності

водного

транспорту, занепад суднобудівної галузі. Суднобудівні підприємства потерпають від браку замовників, а ті, що залишилися партнерами, характеризуються безперервною зміною власників, відсутністю корпоративної культури організації бізнесу, маркетингової політики. Крім того, відсутні фінансові відносини (грошові, кредитні, інвестиційні), які мали б системно впорядковувати процеси технічного та технологічного оновлення виробництва, поповнення оборотних коштів, створення резервів, підвищення компетенції персоналу, здійснення програм у сфері соціального партнерства. I зрозуміло, що, перш за все, має бути сприятлива державна політика, спрямована на створення економічного та фінансового механізмів відтворення умов для оновлення суднобудівної індустрії.

Метою статті $€$ дослідження сучасного стану суднобудівної індустрії та визначення напрямів іiі відновлення i розвитку у контексті реформування транспортної системи країни.

\section{Виклад основного матеріалу} дослідження. Транспортна система в Україні представлена всіма видами транспорту, а її рівнинний рельєф сприяє повсюдному розміщенню шляхів сполучення. Вихід до узбережжя Чорного i Азовського морів, наявність зручних бухт на їх узбережжі вплинули на будівництво морських портів і розвиток морського транспорту. Наявність судноплавних річок (Дніпро, Дунай, Дністер, Південний Буг та ін.) сприяють розвитку річкового транспорту. Тому суднобудівна індустрія - це важлива ланка у забезпеченні функціонування транспортної системи країни, розвиток якої сприятиме повноцінній роботі всієї транспортної інфраструктури, відновленню припортових територій, морських і річкових судноплавних шляхів.

Слід відзначити, що об'єднуючи в процесі випуску своєї продукції досягнення великої кількості суміжних галузей промисловості (металургії, машинобудування, електроніки і так далі), суднобудування одночасно стимулює розвиток цілих галузей, досягнення ними високого науково-технічного рівня. Створення одного робочого місця в суднобудуванні сприяє появі 4-5 робочих місць в металургії, машинобудуванні, електроніки та інших суміжних галузях [1, c. 137].

Проте, перехід суднобудівного комплексу України до роботи в умовах ринкової економіки супроводжувався складними i хворобливими процесами, перебудовою традиційних управлінських структур, паритетних стосунків між підприємствами галузі і замовниками, комерційних зв'язків між постачальниками сировини, матеріалів і комплектуючих для суднобудування [2, с. 41]. Тяжким періодом для суднобудівників України були 90-ті роки, коли рідкісні замовлення 3 вимушеними умовами контрактів все більш послідовно ставили на коліна непристосовані до умов ринку суднобудівні підприємства. Почався хворобливий процес розриву раніше підписаних контрактів, який негативно позначився на формуванні портфеля замовлень та іміджі раніше прибуткових підприємств. Частина договорів 3 різних причин, залишилася діючою, i підприємства суднобудування за рахунок судноремонту, реалізації зайвого устаткування, скорочення соціальної сфери і часткової державної підтримки вимушені були добудовувати судна собі у збиток. Підприємства суднобудування України практично були доведені до стану банкрутства.

В той же час, здійснюючи конверсію виробництва, суднобудівні верфі упродовж 1992-2002 рр. стали освоювати будівництво нових типів удів, конкурентоздатних на світовому ринку, серед яких танкери, призначені для транспортування нафти і нафтопродуктів, балкери для перевезення руди, вугілля i

Вісник економіки транспорту і промисловості № 58, 2017 
зерна, рефрижератори, пасажирські судна, плавучі крани та ін. У період з 2003 по 2010 pp., існуючи на засоби державної підтримки i кошти, які надходили на здійснення ремонту, вітчизняні підприємства суднобудування навчилися шукати на світовому ринку вигідні іноземні замовлення на будівництво окремих корпусів судів.

Слід відзначити, що після розпаду СРСР на території України залишилася потужна суднобудівна база. Основна іiі частина входила в структуру Міністерства промислової політики України, а питома вага iї продукції складала $30 \%$ від загального обсягу всієї суднобудівної продукції СРСР [3, с.13].

Суднобудівна індустрія України представлена зареєстрованими 49 підприємствами (в т.ч. підприємства анексованого Криму), серед яких 11 суднобудівних заводів, 4 підприємства суднобудівного машинобудування, 10 підприємств морського приладобудування, близько 20 науководослідних інститутів і конструкторських бюро, судноремонтні підприємства. Основні суднобудівні підприємства функціонують на тимчасово окупованій території АР Крим, Одеській, Миколаївській, Херсонській областей, у м. Київ.

Але в сучасних складних посткризових умовах господарювання (інфляція, зростання цін на сталь, відсутність фінансових ресурсів, енергоносіїв і комплектуючих) діяльність українських суднобудівників поки що не стала запорукою формування конкурентоздатного вітчизняного суднобудування [4, с. 38]. Серед основних викликів транспортної сфери, що визначають закономірності i напрямки розвитку суднобудівної індустрії необхідно визначити:

підвищення обсягів та інтенсивності переміщення вантажів i пасажирів водним транспортом;

зростання попиту на

перевезення нестандартних, спеціальних вантажів;

впровадження європейських

стандартів i вимог до експлуатації транспортних засобів;

підвищення вимог до

якісних характеристик транспортного обслуговування;

$$
\text { - розширення }
$$

ринку

транзитних послуг та ін.

Аналіз сучасного стану перевезення вантажів і пасажирів різними видами транспорту в Україні підкреслює актуальність i важливість розвитку суднобудівної індустрії, оскільки іiі потенціал не задіяний на повну потужність, що характеризується постійним скороченням частки морського і річкового транспорту (табл.1) [5].

Таблиия 1

Обсяги перевезення вантажів за видами транспорту (млн.тон)

\begin{tabular}{|l|c|c|c|c|c|c|c|}
\hline \multirow{2}{*}{ Вид транспорту } & \multicolumn{7}{|c|}{ Роки } \\
\cline { 2 - 8 } & 2009 & 2010 & 2011 & 2012 & 2013 & 2014 & 2015 \\
\hline Транспорт & $\mathbf{1 6 2 5}$ & $\mathbf{1 7 6 5}$ & $\mathbf{1 8 8 7}$ & $\mathbf{1 8 5 3}$ & $\mathbf{1 8 3 7}$ & $\mathbf{1 6 2 3}$ & $\mathbf{1 5 0 7}$ \\
\hline наземний & 1615 & 1754 & 1877 & 1845 & 1831 & 1617 & 1501 \\
залізничний & 391 & 433 & 469 & 457 & 444 & 386 & 350 \\
автомобільний & 1069 & 1168 & 1253 & 1260 & 1261 & 1131 & 1054 \\
трубопровідний & 155 & 153 & 155 & 128 & 126 & 100 & 97 \\
\hline водний & 10 & 11 & 10 & 8 & 6 & 6 & 6 \\
морський & 5 & 4 & 4 & 4 & 3 & 3 & 3 \\
річковий & 5 & 7 & 6 & 4 & 3 & 3 & 3 \\
\hline авіаційний & 0,1 & 0,1 & 0,1 & 0,1 & 0,1 & 0,1 & 0,1 \\
\hline
\end{tabular}


Як свідчать статистичні дані, у перевезенні вантажів різко виділяється автомобільний транспорт, частка якого залишається досить високою і стабільною, у той час як усіма іншими видами транспорту ці обсяги постійно скорочуються. Особливо стурбовує динаміка перевезення вантажів водним транспортом. За попередні 2012-2015 рр. спостерігається значне зменшення обсягів перевезення вантажів морським транспортом на $60 \%$, річковим - на $50 \%$. Проте, за оцінкою фахівців Міністерства інфраструктури Україна ще не втратила свій потенціал в обслуговуванні вантажопотоків між Свропою і Азією, а іiі портові потужності складають 185 млн.т/рік [6].

Серед основних причин зниження обсягів перевезень вантажів водним транспортом слід відзначити як зовнішні, так i внутрішні фактори, а саме: загальноекономічна криза, скорочення обсягів виробництва основних вантажоутворюючих видів діяльності, скорочення експортно-імпортних перевезень, неповне забезпечення транспорту паливом i запчастинами, нестача транспортних засобів та їх фізичне старіння і незадовільний стан та ін. [7]. До того ж, наявні виробничі потужності морських портів, низький рівень розвитку логістичної інфраструктури морегосподарського комплексу стримують розвиток спеціалізації України, як транзитної держави [8, с.13].

Дослідження світового досвіду функціонування транспортних систем показує, що в таких країнах, як Німеччина, Китай, Великобританія, важлива роль належить морському транспорту, обсяги перевезення вантажів яким зростають 3 кожним роком. Нажаль, Україна в цих показниках значно програє не тільки європейським країнам, а і Росії (табл. 2) [7]. Оскільки в Свропі формується нова мультимодальна Транс'європейська транспортна система, яка включає всі види транспорту та спрямована на побудову Транс'європейської транспортної мережі до 2020 р., то Україні необхідно долучитися до цього процесу, активізуючи застосування інноваційних технологій у перевізному процесі, використання логістичного підходу, поширення мультимодальних перевезень.

Таблиия 2

Обсяги перевезення вантажів морським транспортом (млн. т)

\begin{tabular}{|l|c|c|c|c|c|c|}
\hline \multirow{2}{*}{ Країна } & \multicolumn{7}{|c|}{ Роки } \\
\cline { 2 - 7 } & 2010 & 2011 & 2012 & 2013 & 2014 & 2015 \\
\hline Німеччина & 272 & 292 & 295 & 294 & 300 & - \\
\hline Китай & 218 & 214 & 212 & 216 & 225 & 213 \\
\hline Великобританія & 106 & 104 & 96 & 91 & 95 & 98 \\
\hline Росія & 37 & 34 & 18 & 17 & 16 & 19 \\
\hline Польща & 8 & 7 & 7 & 6 & 6 & 7 \\
\hline Україна & 4 & 4 & 4 & 3 & 3 & 3 \\
\hline
\end{tabular}

Согодні вітчизняний флот практично вичерпав свій фізичний термін служби. Здійснюється його інтенсивне списання, практично без істотного поповнення, оновлення та модернізації. До того ж, складні процеси зміни форм власності, застарілі технології, громіздка інфраструктура, соціальні проблеми зробили підприємства суднобудування збитковими [5].

3 огляду на це, заслуговують уваги дослідження обсягів виробництва i фінансових результатів суднобудівних підприємств України, серед яких сім 
обраних підприємств входять до переліку суднобудівних підприємств, до яких запроваджуються заходи державної підтримки суднобудівної промисловості згідно 3 Постановою Кабінету Міністрів України від 21 грудня 2005 року № 1256 [9], а восьме підприємство - це ПАТ "Чорноморський суднобудівний завод".
На підставі їх фінансової звітності проведений аналіз обсягів виробництва i фінансових результатів за період з 2003 по 2014 роки (3 урахуванням індексів цін виробників промислової продукції по відношенню до 2003 р. за відомостями Держкомстату), результати якого відображено на рис.1.

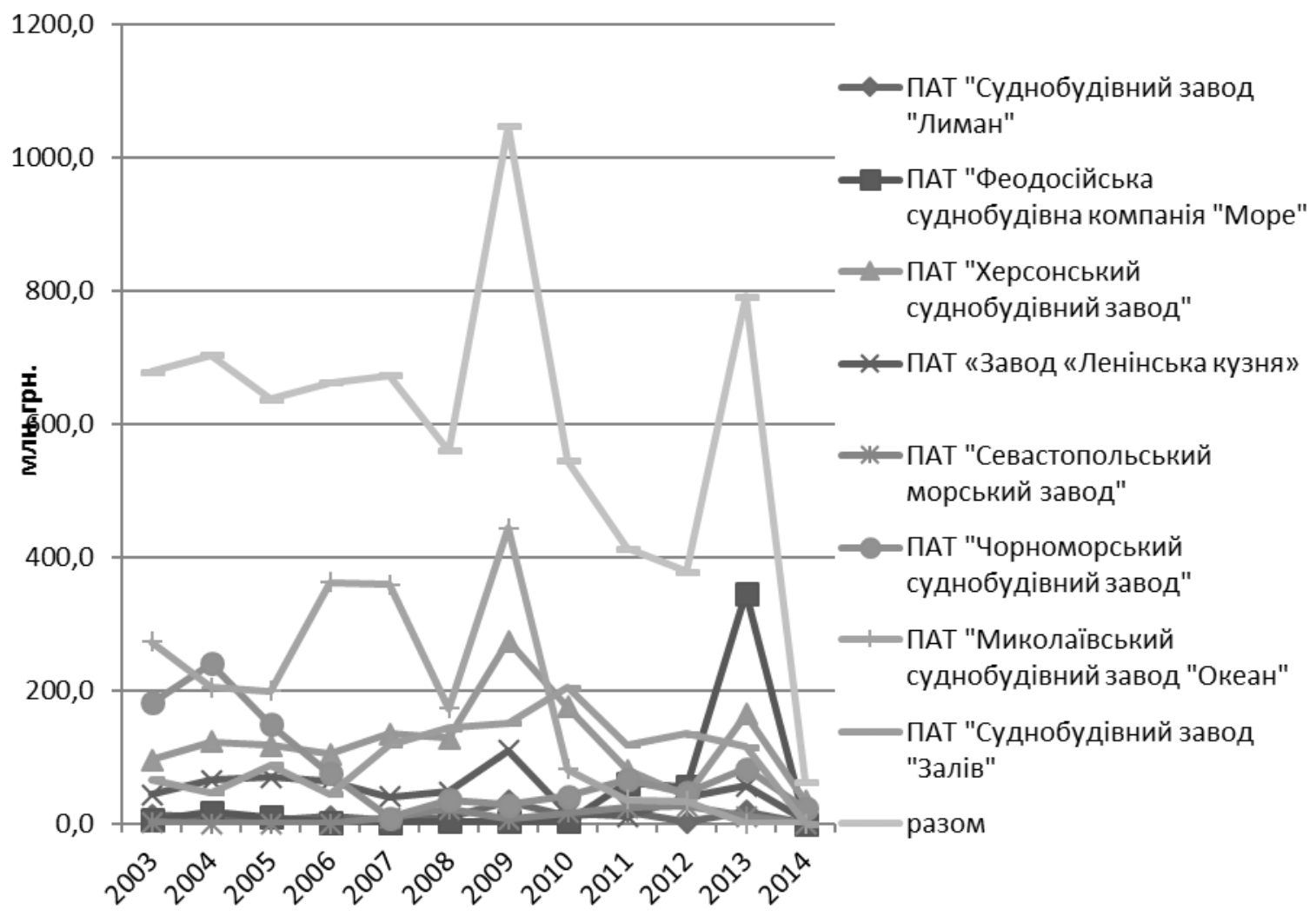

Рис. 1. Динаміка обсягів виробництвва продукиії суднобудівних підприємств

Так, обсяги виробництва (з урахуванням індексів цін виробників промислової продукції) як окремих підприємств, так і групи в цілому поступово знижуються. Виключенням $\epsilon$ зростання обсягів виробництва за підсумками 2009 р., що пояснюється стрибком курсу долара i наслідками світової фінансово-економічної кризи. За оцінками Асоціації суднобудівників України «Укрсудпром» тенденція спаду реалізації продукції суднобудівних підприємств може продовжитися, а через 5-10 років залишиться у кращому разі 2-3 заводи, яким доведеться зіткнутися із зростаючою конкуренцією 3 боку російських суднобудівників [10]. Розглянуті проблеми безпосередньо торкаються і "малого флоту". Останніми роками обсяги перевезень в регіонах Азовського, Чорного і Середземного морів зростають, особливо за такими масовими вантажами як зернові, металопрокат, добрива. У той же час, істотно загострюється положення з флотом суден змішаного, каботажного плавання, загальна кількість яких становить близько 350 суден вантажопідйомністю від 3 до 5 тис. тон з експлуатаційним віком 30-35 років. 3 урахуванням фізичного $\mathrm{i}$

Вісник економіки транспорту і промисловості № 58, 2017 
морального зносу відбувається списання близько 20-30 подібних судів щорічно, а інші мають потенційну небезпеку при експлуатації [3, с.13].

Фінансово-економічний

стан

більшості вітчизняних суднобудівних підприємств протягом останніх десяти років залишається складним, а 2014 рік став найгіршим для їх фінансовогосподарської діяльності. Значних збитків зазнали ПАТ «Чорноморський суднобудівний завод», ПАТ «Херсонський суднобудівний завод». Стосовно фінансових ресурсів суднобудівних підприємств, слід відмітити, що вони отримують більше $2 / 3$ позикових коштів 3 позабанківських джерел. Вони вимушені шукати кредиторів поза банківською системою, оскільки їх не влаштовує рівень процентних ставок і терміни позик (не більше ніж один рік). Такими кредиторами стають у більшості випадків замовники суден, які здійснюють передоплату підприємствам суднобудування, одночасно укладаючи договори 3 іноземними банками, або використовують послуги інших фінансових посередників. Останнім часом суднобудівні підприємства змушені використовувати амортизаційні відрахування, призначені на повне відновлення основних фондів, в поточному господарському обороті. На ринку українського суднобудування значну частину складають миттєві розробки, a прикладним i фундаментальним дослідженням увага не приділяється.

Слід також звернути увагу і на те, що сьогодні суб'єкти господарювання вітчизняного морегосподарського комплексу відчувають ще більші фінансові втрати внаслідок відміни пільг і підвищення податкового навантаження в силу прийняття 31.01 .2015 p. змін до Податкового кодексу України [11]. Якщо в 2011-2014 pp. такі підприємства мали пільги щодо податку на землю, то в сучасних умовах сплата повної суми відповідного податку являється вагомою загрозою

економічній

безпеці

суднобудівних підприємств.

Техніко-технологічне

оновлення суднобудівного

виробництва, модернізація існуючої інфраструктури морських і річкових портів могли б значно збільшити потужності всього морегосподарського комплексу України. Будівництво каботажного флоту цілком під силу ряду промисловим i сільськогосподарським комерційним підприємствам України. Про це свідчить досить короткий, але ефективний досвід компанії «Нібулон», яка $\epsilon$ найбільшою в області транзиту сільськогосподарської продукції морегосподарським комплексом України. За неповні три роки судноплавна компанія випустила більше 50 різнотоннажних судів, побудованих як на верфях Миколаєва, так і на власному суднобудівному підприємстві. Географія роботи цієї компанії охоплює значну частину річкових регіонів та морських терміналів, досвід іiї розвитку свідчить про великі перспективи в області переробки сировини із застосуванням нових технологій.

Досвід європейських країн свідчить про їх лідерство у будівництві особливо складних суден (до 80\%), тільки 6\% складають "прості" судна, а за тоннажем Свропа будує близько $20 \%$ усіх видів суден. Портфель замовлень складає близько 58 млн. GT, 3 яких 26,4 \% належить Південній Кореї, 2,5\% - Японії, $6 \%$ - Італії, по 5\% - Німеччині і Китаю, 3\% -Голландії. Збільшення портфелю замовлень (з початку 90-х років) призвело до росту виробничих потужностей у світовому суднобудуванні і як результат до зниження цін на нові судна. Це пов'язано 3 надлишком виробничих потужностей в Південній Кореї, суднобудування якої використовує чинник державної підтримки (дотації верфям до $20 \%$ ) та зі спадом в економіці і фінансовою кризою в Далекосхідному регіоні. Можна сподіватися, що найближчими роками виробничі

Вісник економіки транспорту і промисловості № 58, 2017 
потужності в суднобудуванні знизяться, враховуючи, що уряди більшості держав зменшують свої субсидії на захист національних суднобудівників [12].

В умовах національної економіки суднобудівні виробники можуть досягти успіху за умови дієвої державної підтримки 3 використанням державних програм, причому як на ринку фінансових ресурсів, так і в правовому, і податковому полі. Стосовно фінансової складової, то слід відзначити, що українські банки, визначаючи свою політику в області кредитування, враховують як попит на власні послуги, результати аналізу фінансового стану позичальників, так i особливості пропозиції ринку відповідних продуктів. Особливо це стосується підприємств суднобудівної галузі. Після 1991 року в незалежній Україні підприємства суднобудування обслуговувалися Промінвестбанком, клієнтами якого були ЧСЗ, завод ім. 61 Комунара, завод «Океан». Зараз підприємства суднобудування обслуговуються в різних банківських установах. Для банків суднобудівні підприємства - це передусім потенційні позичальники, які виставляють особливі умови до обсягів кредиту, термінів і до плати за кредит. Окрім замовників суден, кредити потрібні безпосередньо суднобудівним підприємствам та їх контрагентам - постачальникам устаткування, комплектуючих матеріалів.

Тому одним 3 фінансовоекономічних важелів оновлення підприємств суднобудівної індустрії має стати створення Національного Бюро розвитку суднобудування (НБС), в діяльності якого повинні брати участь колегіально всі структури морегосподарського комплексу, державні структури, банківські та інші фінансові установи. Створення сприятливих нормативних i фінансових умов для розвитку суднобудівної галузі, формування надійного інвестиційного клімату мають бути основними цілями формування і функціонування НБС. А їх досягнення свідчитиме про зважену підтримку суднобудівної галузі 3 боку держави, стимулювання економічних інтересів у вкладення значних фінансових ресурсів в довгострокове кредитування українських судновласників i суднобудівників, вирішення фінансових проблем поповнення їх оборотних коштів внаслідок зниження процентного i строкового навантаження за кредитами, тощо. До того ж, банківські корпорації, як учасники НБС, можуть пропонувати лізингові послуги, які мають багато переваг порівняно із іншими способами фінансування будівництва або придбання нових суден. Для ефективного застосування лізингу в українському суднобудуванні потрібне залучення для такої діяльності великих банків, які здатні організувати замовлення, фінансування i будівництво суден на підприємствах галузі i забезпечити їх довгостроковий лізинг. Подібний досвід знайшов застосування у світовій практиці, коли держава оголошує конкурс, за результатами якого розподіляються бюджетні кошти, виділені державою на розвиток i підтримку лізингу в суднобудівній галузі.

Висновки. Однією із важливих складових розвитку конкурентоздатної вітчизняної транспортної системи являється відновлення потенційних можливостей морського транспорту та суднобудівної індустрії, як його підгрунтя. Підтримка вітчизняного суднобудування державою, формування сприятливих умов для залучення інвестицій, надання податкових та інших пільг сприятиме ефективному функціонуванню морегосподарського комплексу України. Серед основних завдань досягнення такої мети слід визначити наступні:

$\begin{array}{lrr}- & \text { створення умов } & \text { для } \\ \text { ринкового саморегулювання } & \text { галузі } \\ \text { (лібералізація), } & \text { ліквідація } & \text { або } \\ \text { перепрофілювання } & \text { частини підприємств }\end{array}$


суднобудування, які не можуть витримати ринкової конкуренції;

фінансова підтримка галузі 3 боку держави (розміщення і фінансування державних замовлень, виконання державних програм розвитку) методом прямого регулювання;

використання політики

державного протекціонізму (методи непрямого регулювання), які полягають в створенні сприятливих нормативних, фінансових i податкових умов для розвитку галузі, надійного інвестиційного клімату.

Подальша державна політика у галузі суднобудування повинна бути спрямована на створення Національного Бюро розвитку суднобудування 3 правами міністерства, в структурі якого мають бути задіяні професійні кадри 3 представників морегосподарського комплексу (фахівці в області логістики, фінансів, юриспруденції, інженерисуднобудівники, аудитори). Така структура могла б представляти інтереси держави, суб'єктів господарювання i бізнесових структур, спрямовані на відновлення суднобудівної індустрії на шляху поглиблення інтеграції України до європейської та світової транспортних систем, в тому числі і в систему світових морських перевезень.

\section{ПЕРЕЛІК ВИКОРИСТАНИХ ДЖЕРЕЛ}

1. Пашко Д. В. Сучасний стан i перспективи розвитку суднобудування в Україні / Д. В. Пашко // Економічні науки. - 2011. - № 1. - С. 137-139.

2. Буркинський Б.В. Концептуальні засади реструктуризації суднобудування України / Б.В. Буркинський, Г. В. Єфімова // Економіст. - 2010. - № 7. - С. 39-42.

3. Фінанси суднобудівних підприємств: монографія / Воробйова I. А., Карась П. М. [та ін.]. - Миколаїв: НУК, 2012. - 234 c.
4. Сфімова Г.В. Прийняття інвестиційних рішень в суднобудуванні: монографія/ Г. В. Сфімова, О. В. Пащенко. - Миколаїв, НУК, 2010. - 108 с.

5. Офіційний сайт Державної служби статистики України // [Електронний ресурс]. - Режим доступу: http://www.ukrstat.gov.ua

6. Офіційний сайт Міністерства інфраструктури України // [Електроний ресурс]. - Режим доступу: http://www.mtu.gov.ua.

7. Котлубай О.М. Економічні механізми розвитку торгівельного мореплавання в Україні: наукова монографія / O.M. Котлубай. - Одеса: ІПРЕЕД НАН України, 2004. - 453 с.

8. Іртищева I.O. Стратегічні орієнтири розвитку логістичної інфраструктури в морегосподарському комплексі України / I. О.Іртищева, Т.В.Стройко //Збірник наукових праць НУК.-Миколаїв: НУК, 2014. - № 1(451). C. 12-17.

9. Постанова Кабінету Міністрів України від 21 грудня 2005 року № 1256 «Про затвердження переліку суднобудівних підприємств, для яких запроваджуються заходи державної підтримки суднобудівної промисловості» // [Електронний ресурс]. - Режим доступу: http://zacon.rada.gov.ua.

10. Офіційний сайт Асоціації суднобудівників України «Укрсудпром» // [Електроний ресурс]. - Режим доступу: http://www.ukrsudo.kiev.ua.

11. Закон України від 28 .12.2014 № 71-VIII «Про внесення змін до Податкового кодексу України та деяких законодавчих актів України щодо податкової реформи»// Відомості Верховної Ради (ВВР). - 2015. - № 7-8. - С 9.

12. Суднобудівна галузь України та

iii конкурентоспроможність // [Електронний ресурс] - Режим доступу: http: // www.br.com.ua/
13.
Александров
В. Л. Судостроительное предприятие в

Вісник економіки транспорту і промисловості № 58, 2017 
условиях рынка: проблемы адаптации и развития / В.Л. Александров, А. В. Перелыгин, В. Ф. Соколов. - СПб.: Судостроение, 2003. - 424 с.

14. Александровская Н. И. Производственный потенциал судоремонтных и судостроительных предприятий Украины с учетом их расположения / Н. И. Александровская, А. В. Кошарская, В. Д. Евдокимов // Зб. наук.праць ОМНУ. - 2009. - №1. - С. 111119.

15. Жихарева В. Умови ефективної реалізації інвестицій у розвиток флоту суднобудівних компаній України / В. Жихарева // Економічний аналіз. - 2010. №7. - C. 45-47.

16. Макогон Ю. В. Украина держава морская / Ю. В. Макогон, А. Ф. Лысый, Г. Г. Гаркуша, А. В. Грузин. - ДонНУ, 2010. - 393 с.
17. Пирожков С. Проблемы реализации транзитного потенциала Украины в контексте расширения ЕС и формирования ЕЭП / С.Пирожков, Д.Прейгер, И.Малярчук // Экономика Украины. - 2005г, - № 3. - С.4-19.

18. Integration of Ukraine into the world maritime complex [Електронний pecypc] / I.R. Iarmolovych, D.I. Iarmolovych // Економіка: реалії часу. - 2015. - № 1(17).-C.190-194.

19. H.Mäkinen.The Russian maritime industry and Finland/Electronic Publications of Pan-European Institute,2/2015.[Електронний ресурс] Режим доступу: http: // www.utu.fi/pei

20. Jean-Paul Rodrigue, Brian Slack .Intermodal Transportation and Containerization Authors.[Електронний ресурс] - Режим доступу: https://people.hofstra.edu

УДК 656.025.2(477)

\title{
РЕФОРМУВАННЯ І СУСПІЛЬНІ ЕФЕКТИ ПАСАЖИРСЬКИХ ПЕРЕВЕЗЕНЬ ЗАЛІЗНИЧНОЇ ГАЛУЗІ
}

\author{
Слагін Ю.В., к.е.н., доцент, \\ Проценко Н.О., махістр (УкрДУЗТ)
}

\begin{abstract}
Транспорт впливає на: здоров'я $i$ життя населення;стан атмосфери $i$ біосфери; раціональне використовування природних та енергетичних ресурсів; забезпечення сталого розвитку краӥни. Залізничні пасажирські перевезення для суспільства більш ефективні ніж автомобільні за рахунок значно менших «зовнішніх витрат» залізничного транспорту. Субсидування перевезень відповідає інтересам суспільства і економіки, адже призводить до зниження зовнішніх витрат(«витрат переливу») пасажирських перевезень; збільшення мобільності населення, сприяє підвищенню якості трудових ресурсів і якості життя населення, дає довготривалий макроекономічний ефект для усієї країни. Необхідна розробка законодавчого механізму субсидування пасажирських перевезень залізничним транспортом, який буде гарантувати збереження та розвиток пасажирського залізничного комплексу після ліквідації перехресного субсидіювання пасажирських перевезень.
\end{abstract}

Ключові слова: пасажирські перевезення, реформування залізничного транспорту, сталий розвиток, витрати суспільства, суспільні ефекти транспорту. 